\title{
荒天中の自動操舵と Yawingについて
}

\section{正員 工学士 元 良 誠 三}

\author{
Abstract \\ On the Automatic Sheering, and Yawing of Ships in Rough Seas
}

By Seizo Motora, Kogakushi, Member.

According to the records of actual ship experiment on S.S. Nisseimaru in the North Pacific Ocean last, year steering angle in automatic steering condition often exceeds 20 degrees in heavy storm, and the loss of amount of horsepower due to this excessive steering cannot be overlooked.

The steering angle in the above condition exceeds the amount necessary to hold the ship's course straight, and even causes the ship to yaw beyond the natural yawing by waves.

The author investigates in this paper into the relationship between steering angle and her condition, and finds, there is relationship between excessive steering angle and relative wind direction, and notes that the phase lag in steering due to "weather adjust" is one of the important causes of excessive steering and yawing.
目 次
$\S 1 . \quad$ 緒 論
§2. 操舵角度と海象の関倸
$2 \cdot 1 \quad$ 波による Yawing
$2 \cdot 2$ 操舵角度と風向との関倸
2.3 操舵角度と風速との関保
§3. 操舵の為の馬力損失

\section{2 舵の抵抗}
§4. 大角度操舵の原因
$4 \cdot 1$ weather adjust と位相差
4.2 偏角之舵角の位相差が航珞安定性 に改ぼす影響
$4 \cdot 3$ 過大操舵防止に対する一方法

\section{§1. 緒論}

昨年行われた日聖丸による実船試験の記録によると, 荒天中の操舵角度は自動澡舵中で 20 度を超える事があ り，この角度は我々の予想をかなり上迴るものであつた。

船の方位角と，之に対応する操舵角とを代表的な数例について示すと第 1 図の如くである。第 1 図の短週期 (約 7 秒) の Yawing は，一波每に波圧によつて生じた Yawing であり，其振巾も大体理論的1)に予想される 量と一致して居り，又週期も波の出会週期と一致している。

この他に長週期（約 70 秒）の大角度の Yawing と云うより蛇航が之に重つているのが見られる。そしてこ れと同じ週期で大角度の操舵が行われている。この様な長週期の週期的な外才は考觉られないから, 後者は操舵 によつて生じた蛇航であり，その週期は自動操緃装置のサーボ機苹に於ける固有週期であると思われる。

この事から自動操舵の角度は船の航路を保つ目的を超えて居り, 或場合にはこの操舵の為に不必要な蛇航を生 じて居るのではないかとの疑問を生じて来る。

本論文では, この大角度の操舵と，その時の海象状態の関連と，その為に生ずる馬力損失につき調疽し，更に 何故にこの椂な大角度の操舵を起すかの原因を考慮した。

\section{§2. 操舵角度と海象の関係}

第 1 表は橫浜出航より Vancouver を経て Honollulu 汽の各実験番号”に於汁る舵角, Yawing，及海象 


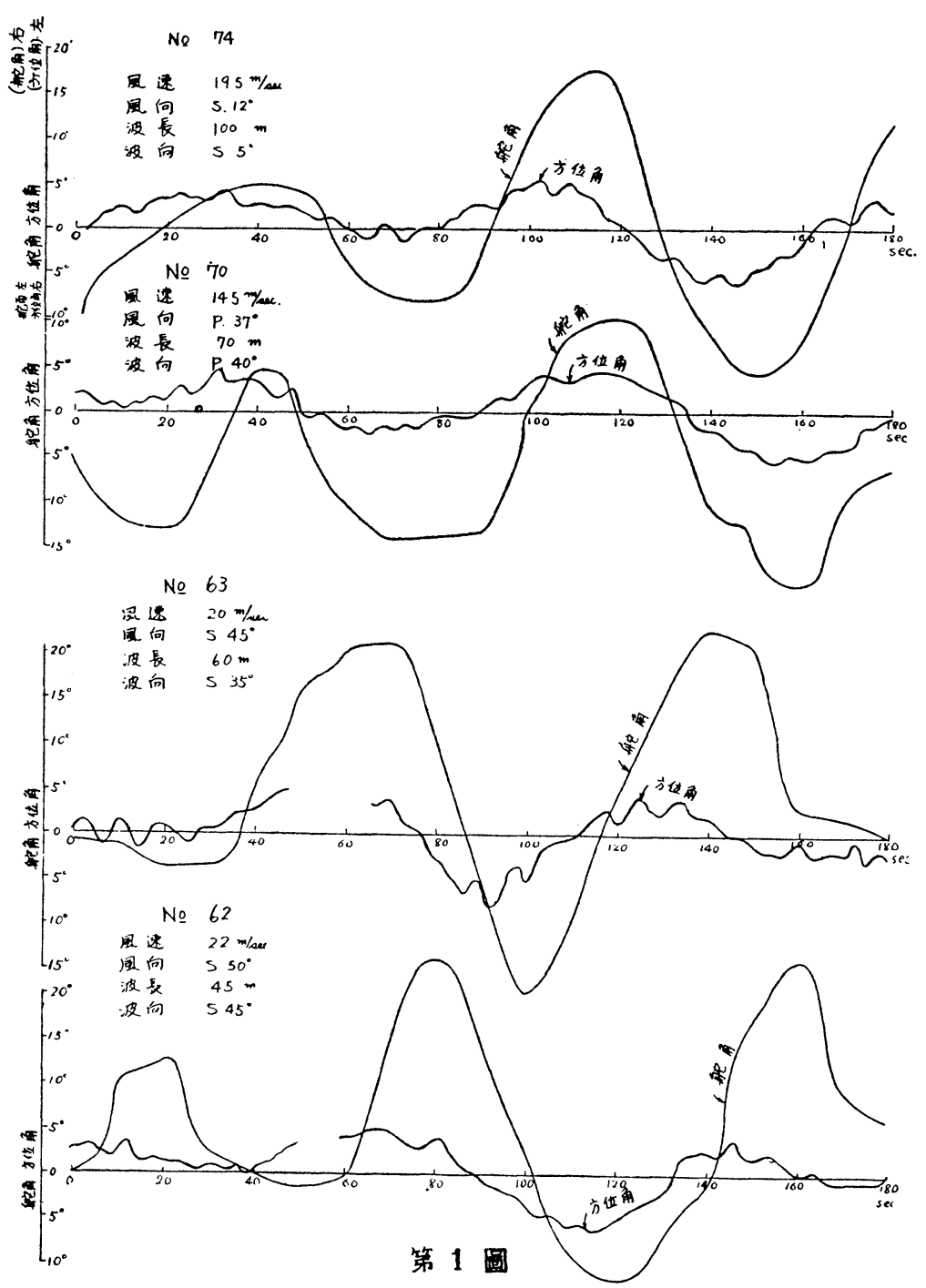

状態を示すもので, 表中, 平均舵角とは右左両方の舵 角を全部符昂を等しくして 平均したものであり, 平均 抵抗とは, 左右別々の平均 の差である。(第 1 図参照) 徥つて前者は大体舵角の 変動を示し, 操舵の為の抵 抗の增加は, 略々この平均 舵角比比例寸る。

又後者汢平均して舵がど ちらの舷に片寄つて居たか を示すもので, 船を航路よ り外れさせようとする外力 の偶力に略々比例するもの と考えられる。（頁数の関 係で算 1 表省略)

2・1. 波による Yawing 波による一波每の $\mathrm{Ya}$ wing は例觉ば第 1 図 No. 74 では約 $1.5^{\circ}$ 程度である。 波浪中の治制偶力は論 交1によつて計算すると，

$$
\begin{aligned}
& \text { 迎角 } \alpha=5^{\circ} \\
& \text { 波長 }=100 \mathrm{~m} \\
& \text { 波長 } / \text { 船長 }=0.78 \\
& \text { 莨高/波長 }=1 / 20 \\
& \text { に対し 偶ナ } N=0.02 W . L \\
& \text { 但し } W \cdot \text {. 船の排水量 } \\
& L \cdot \text {. 船の長さ }
\end{aligned}
$$

之より Yawing に対する

抵抗を無視して Yawing の振巾を求めると，

$$
\theta=\frac{N}{\left(\frac{2 \pi}{\tau}\right)^{3} \times \frac{1}{I}} \quad \begin{aligned}
& I \cdot \text { 但し 船の垂㨁軸の团りの慣動半径 } \\
& \tau \cdots \text { 出会週期 }
\end{aligned}
$$

この式に数値を入れて略算すると $\quad \theta=1.5^{\circ}$

を得る。從つて波によつて生ずる Yawing の量は理諭的に予想される程度であり, 又この為著しく推進性能が 害される事はない。

\section{2. 操舵角度と風向との関係}

第 1 表より操舵角度と風向との関係を plot すると第 2 図の如くなる。図中黑丸は往航軽荷状態を示し, 白丸 は復航澫載状態を示す。

第 2 図を見ると平均舵角の方は風向によつて大した変化はないが，平均抵舵の方は朋膫て風が左舷から吹く時 と右舷から吹く時とで方向が逆になつている。

この傾向は满載時によく現われ，舵は常に風の吹いて居る舷の側光抵舵されている。これは中㿟氏の論交 述べられている如く, 風が船体に及改す力と, 船体が drift する為水から受ける水圧力の作る偶力がこの場合は 
本圴舵角及び平均抵舵と風向の闲係
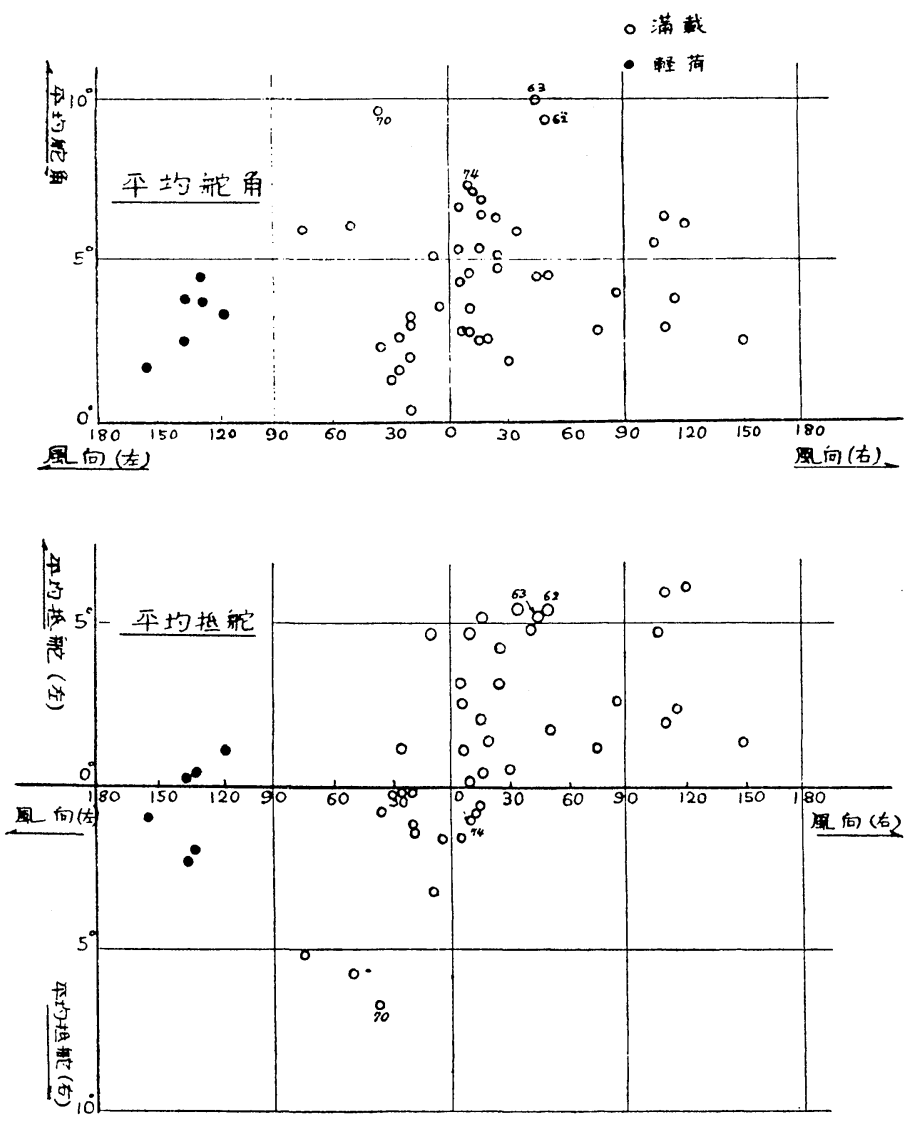

第 2 圖

船を風上側に立てようとする方向に 働く事を示す。（第 3 図（a）参照） この事は日聖丸の沿橋が比較的船体 中央に近く，且垂㨁な壁面を有する 事からも予想される事である。

軽荷洔は data が少く，はつきり した事は判らないが, 满載の時とは 逆にやや風下に落ちる傾向を示し二 いる。これは軽荷時こ大きな船尾卜 リムるつ外為に, 水圧中心が後方 え寄り，偶力が逆となるものと考光 られる。

船の航路き保つ上から云らと, 満 載洔の如く風に立つ方が望ましい。 即ら風圧力による船の drift が幾分 でも舵の才によつて阻止されるふら である。

(a)

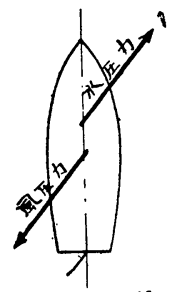

第 3 圖 (b)

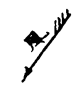

份この平均抵舵に相当する舵角を 定常的に取つた特に生ずる偶力が風 の偶力に等しいと考えて第 1 図の数 例について計算して見ると第 2 表の 様になる。

\section{2·3. 風速との関係}

第 2 表

\begin{tabular}{|c|c|c|c|c|c|}
\hline 実 & 験 No. & 船 & 速 & 平均抵舵 & 偶 \\
\hline & 62 & & & $5.35^{\circ}$ & $742 \mathrm{t}-\mathrm{m}$ \\
\hline & 63 & & & 5.48 & 760 \\
\hline & 74 & & & 0.36 & 70.4 \\
\hline
\end{tabular}

第2図は風速の大小を考慮せずに plot したものであるが，若しこの舵角の変動が風の為に生じたものとすれ ば風圧力は風速の二乗に比例するから，平均舵角，平均抵舵を風速の二乗で割れば第 2 図の点は多小䋲つて来る 事が考えられる。

第 4 図はその結果を示す。第 2 図に対しさして爡まつたとは云えないが，第 2 図では真正面の風に対して舵角 の変動及び抵抗が大きく出て居るのに対し第 4 図ではむしろ $90^{\circ}$ 附近の風向の時が大きくなつている。

これは隅々Vancouverより横浜に向う間に正面近くの遥風を受けた日が続いた為であつて，操縌性の見地か らは真横の強風を受けた時の方が不利である事を示す。

\section{§3. 操舵の為の馬力損失}

$20^{\circ}$ を超える操舵を行えば，その為の馬力の損失も決して小さくない事が考えられる。操舵及びその為の蛇航 の為の馬力損失の原因として次のものが考えられる。
1. 遠心力の分力
2. 舵の抵抗
3. 斜航の為の抵抗
4. 走行距離の延長
5 操舵機の馬力損失 
园速及び罢と向と舵角の肉係

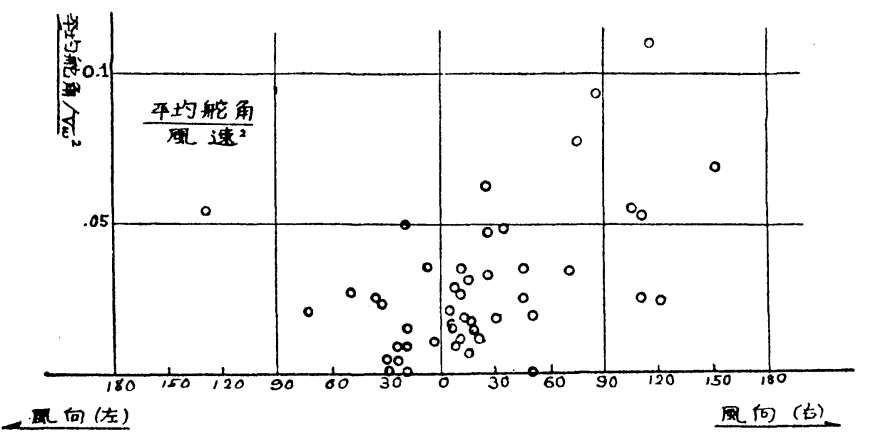

この内，3，4，はかなりの蛇航をしな い限り大して抵抗堌加にならない事は論 交1に述べた通りで，ここでは無視し， 5 も余り大きくないと考兄られるので省 略する。

\section{3・1. 蛇航遺心カによる抵抗增加}

第 1 図の例につき附録 1 に示寸様な方 法で計算して見ると第 3 表の如くなる。

\begin{tabular}{|c|c|c|c|}
\hline 笑験 No. & - 蛇航振幅 & 週 期 & $\overline{y R}$ 平均抵抗 \\
\hline 62 & $6^{\circ}$ & $70 \mathrm{sec}$ & $3.23 \mathrm{t}$ \\
\hline 63 & $5^{\circ}$ & "I & $2.25 \mathrm{t}$ \\
\hline 74 & $5^{\circ}$ & "I & $2.25 \mathrm{t}$ \\
\hline
\end{tabular}

\section{2. 舵の抵抗}

舵角の変動による舵自体の抵抗を平均 したものを附録 2 の如き方法で求めて見 ると第 4 表の様汭る。

自(右) 第 4 表

\begin{tabular}{c|c}
\hline 実 験 No. & 平均抵抗 $\bar{R}_{r}$ \\
\hline 62 & $2.25 \mathrm{t}$ \\
63 & 2.59 \\
74 & 1.33 \\
\hline
\end{tabular}

两者を加兄て操舵の然の抵抗増加及び 馬力の損失を求めて見ると，第 5 表の様 になる。

この結果を見ると操舵の為の馬 力損失は看過出来好すがある。 勿論この操舵の為の馬力損失を全 く無くする事は出来ないが，平均 抵舵の附近で $\pm 5^{\circ}$ 程度の変動化 押穴られれば蛇航も少なくなり馬 力損失も格段に滅少するであろう。

第 4 圆
第 5 表

\begin{tabular}{|c|c|c|c|c|c|}
\hline \multirow{2}{*}{ No. } & \multirow{2}{*}{$\overline{R_{y}}+\overline{R_{r}}$} & \multirow{2}{*}{ 船 速 } & \multirow{2}{*}{ 馬力損失 } & \multicolumn{2}{|c|}{$E H$ との比 } \\
\hline & & & & $\eta=0.6$ & $\eta=0.5$ \\
\hline 62 & $5.48 \mathrm{t}$ & $5.12 \mathrm{~m} / \mathrm{sec}$ & $375 \stackrel{P}{ }$ & $19.7 \%$ & $23.7 \%$ \\
\hline 63 & 4.84 & 4.46 & 288 & 14.8 & 17.8 \\
\hline 74 & 3.58 & 4.48 & 214 & 10.5 & 12.6 \\
\hline
\end{tabular}

次にこの様な大角度の操舵の原

因は何処にあるか，又不可避なるのであるかどうかについて考察して見たい。

\section{§4. 大角度操舵の原因}

\subsection{Weather adjust と位相差}

第 1 図を見ると, 船の方位角の変動に対し舵角の変動は常に 5〜10 秒程度遅れて起つて居るのが判る。この遅 れは航路保持の為に有害である事は Minorsky4) が指摘して居る通りである。

以下この位相差を生ずる原因を考えて見る。

現在用いられている自動操舵の方式は，船の予定コースよりの偏り角に比例して舵角を取る方式である。

偏角はデヤイロコムパスによつて検出され，偏角を生ずるや否や電気接点が接触して操舵が初り，操舵角と共 に接点が移動して偏角に比例した舵角汽動いて静止する。静水中ではこの電気接点には殆んど間覙が無く, 舵は 鋭敏に偏角に応じて取られるが, 荒天中では波の為に Yawing を生じて, 偏角は週期的に変動し, 特に迎波の 


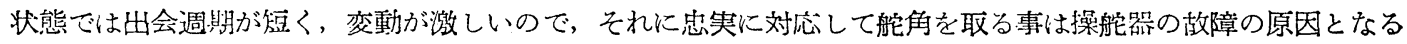
ので所謂 weather adjust を行5。

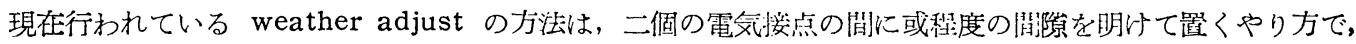
之により短週期の細かいY Yawing は一々舵角に 伀洼されず，その外側を連㸚る線が伝避されるわ けである。若し Yawing の振巾が一定していて, 接点間隔が丁度その浱巾と等しい場合には舵角は 方位角の平均線に比例して取られ位相差を生じな いが, Yawing が不規則であり，且援点间隔が大 きい場合には第 5 図の如く舵角には多少の䐅れを

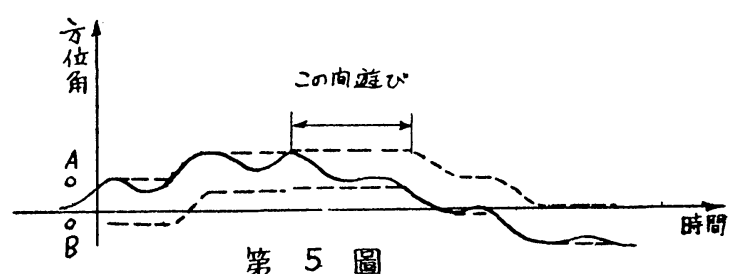

第 5 圆

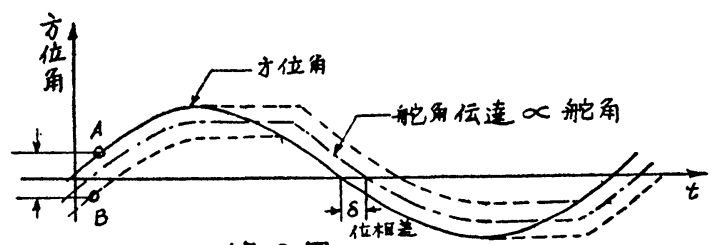

第 6 圆 ば左に動いて最大に洋し，右に転ずる際に2s の 遊びを生ずるので, 結局 $\delta$ だけの位相差を生じ,

$$
\delta=S /\left(\frac{d \theta}{d t}\right)_{\max }
$$

Yawing の浱巾を $\Theta$ ，週期をてとすると，

$$
\delta=\frac{\tau \mathcal{S}}{2 \pi \Theta}
$$

例えば $\Theta=5^{\circ} \quad s=2^{\circ} \quad \tau=70 \mathrm{sec}$ とすると, $\delta=4.6 \mathrm{sec}$

この外にも位相差を生ずる原因があるか子知れないが，これが主要な原因となつているるのと思われる。

\section{4・2. 偏角と舵角の位相差が航路安定性に及ぼす影響}

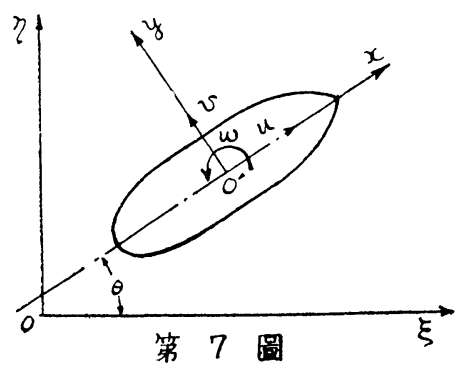

第 7 図に於て，船体に固定して $x \boldsymbol{o}^{\prime} y$ 軸を取る。

船の中心線が $\xi$ 軸と為す角、

前進速度

漂流速度

回転角速度

$y$ 万向の外力を

回転偶力を

前進速度は不変なるのとして即ち $\Delta \boldsymbol{u}=0$ 光として運動方程式を作ると， 論交5) に求められて居る如く

$$
\left.\begin{array}{l}
\frac{d \Delta v}{d t}=\mu_{2} \Delta v+\mu_{3} \Delta w+Y \\
\frac{d \Delta w}{d t}=\nu_{2} \Delta v+\nu_{3} \Delta w+N
\end{array}\right\}
$$

但し $\mu_{2}, \mu_{3}, \nu_{2}, \nu_{3}$ は航型攻び前進速度によつて变化する係数である。

今舵角を $\theta$ に比例して取るとして比例係数を $\boldsymbol{c}$ とすると，

$$
\left\{\begin{array} { l } 
{ N = - k _ { \theta } \cdot a } \\
{ Y = k _ { y } \cdot a }
\end{array} \quad a ( \text { 舵角 } ) = c \theta \text { 故 } \quad \left\{\begin{array}{l}
N=-k_{\theta} \cdot c \cdot \Delta \theta \\
Y=k_{y} \cdot c \cdot \Delta \theta
\end{array}\right.\right.
$$

（1）式に代入すると,

$$
\left\{\begin{array}{l}
\frac{d \Delta v}{d t}=\mu_{2} \Delta v+\mu_{3} \Delta w+k_{y} c \Delta \theta \\
\frac{d \Delta w}{d t}=\nu_{2} \Delta v+\nu_{3} \Delta w-k_{\theta} c \Delta \theta
\end{array}\right.
$$


之より $\Delta v$ を消去すると $\Delta w=\frac{d \Delta \theta}{d t}$ なる事を考えて

$$
\frac{d^{3} \Delta \theta}{d t^{3}}+q_{1} \frac{d^{2} \Delta \theta}{d t^{2}}+\left(q_{2}+k_{\theta} c\right) \frac{d \Delta \theta}{d t}+\left(-\mu_{2} k_{\theta} c-\nu_{2} k_{y} \cdot c\right) \Delta \theta=0
$$

この $\Delta \theta$ の安定条件は

$$
\text { 但ᄂ } q_{1}=-\left(\mu_{2}+\nu_{3}\right) \quad q_{2}=\left(\mu_{2} \nu_{3}-\nu_{2} \mu_{3}\right)
$$

$$
\left\{\begin{array}{l}
q_{1}>0 \\
q_{1}\left(q_{2}+k_{\theta} \cdot c\right)+\left(\mu_{2} k_{\theta} \cdot c+\nu_{2} k_{y} c\right)>0 \\
-\left(\mu_{2} k_{\theta} \cdot c+\nu_{2} k_{y} \cdot c\right)>0
\end{array}\right.
$$

この条件が満たされれば船は何等かの外力により原航路より外れても又元の方向へ戾るわけである。过に前迹の， 理由で方位看 $\theta$ と舵角 $\alpha$ との間に $\delta$ なる時間の遅れがある場合には Minorsky $\left.{ }^{4}\right)$ が取扱つた椂に

$$
\alpha=c \theta(t) \quad \text { が } \quad \alpha=c \theta(t-\delta)
$$

となるから

$$
\left\{\begin{array}{l}
N=-k_{\theta} c \cdot \theta(t-\delta)=-\left(k_{\theta} \cdot c-k_{\theta} c \cdot d \theta \frac{d \theta}{d t} \delta\right) \\
Y=k_{y} c \cdot \theta(t-\delta)=k_{y} c \theta-k_{y} c \frac{d \theta}{d t} \delta
\end{array}\right.
$$

従つて (4) 式第三項の係数は

$$
q_{2}+k_{\theta} \cdot c+\left(\mu_{2} k_{\theta} \cdot c+\nu_{2} k_{y} \cdot c\right) \delta \quad \text { となる。 }
$$

微つて安定判別式 (5) は

$$
\left\{\begin{array}{l}
q_{1}>0 \\
q_{1}\left(q_{2}+k_{\theta} \cdot c\right)+\left(\mu_{2} k_{\theta} \cdot c+\nu_{2} k_{y} \cdot c\right)\left(q_{1} \delta+1\right)>0 \\
-\left(\mu_{2} k_{\theta} \cdot c+\nu_{2} k_{y} \cdot c\right)>0
\end{array}\right.
$$

となる。即ち判別式第二式に新たに $\left(\mu_{2} k_{\theta} \cdot c+\nu_{2} k_{y} \cdot c\right) q_{1} \delta$ なる項が加わるわけである。

然るに第 3 式より安定なる船（操舵方向が偏角と逆方向になつている船）では $\left(\mu_{2} k_{\theta} \cdot c+\nu_{2} k_{y} \cdot c\right)$ は傎であるか ら位相差 $\delta(\delta>0$ が遅れ) は安定性に不利な影響を与える事になる。

今例について計算して見ると，論文 ${ }^{5)}$ より日聖丸に大体相当した数值を取つて来ると

$k_{\theta}=0.583 \quad k_{y}=0.0697 \quad c=3$ (第1図より取る) $\quad \mu_{2}=-3.02 \quad \nu_{2}=-6.152 \quad q_{1}=4.04 \quad q_{2}=2.013$ 之を用いると

1) 遅れの無い場合，安定判別式（5）は

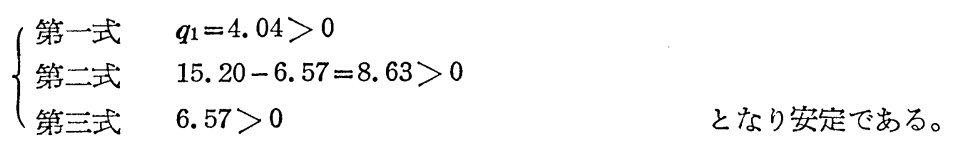

2）次に 10 秒の遅れがあつたとすると，1）式の係数は総て結の長さにつき相似な係数で表わされているふら $\delta=10 / \sqrt{L}=10 / \sqrt{128}=0.883$

之を安定判別式 (9) に入れると

$$
\begin{cases}\text { 第一式 } & 4.04>0 \\ \text { 第二式 } & 15.20-6.57(1+4.04 \delta)=-14.80<0 \\ \text { 第三式 } & 6.57>0\end{cases}
$$

となつて遅れの為に不安定となる。

湖どの程度の遅れがあると不安定になるかを求めて見ると $\delta=3.7 \mathrm{sec}$ となる。

この事から，荒天時迎波の状態では weather adjust の為に舵局の伝達に迤れを生ずる結果船は力问的に不 安定に陷り，偶々強風による偶力で船が航路より外されようとして大盾度の操舵を桥起するものと思われる。

往航時, かなりの荒天にも拘らず大して舵角が大きくなく, 又長週期の蛇航を生じていないのは, 遍波の為出 会週期が長いので weather adjust をしていない為と考えられる。份蛇航の週期些大体 70 sec 位であるが, 之は操舵系の固有週期であろう。

\section{3. 過大操舵防止に対する一方法}


以上述べて来た如く, 大角屡の操舵の原因が注として weather adjust による位相差による事が判つたので, 荤れを生じない永な調節方法があれば理想的なわけである。

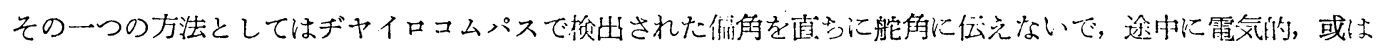

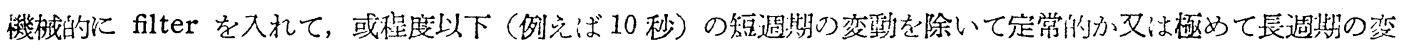
動丈を伀える椂にする方法がある。

機械的にはスプリングと damper により，電気似にはコンデンサーとチョークによつて比較似容易に目的が 達せられるのではなからうか。

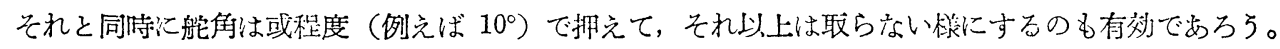

第 2 図から見られる様に平均抵舵は大体 6 止りであるから, 風による偶力の平均は最大この程度の舵角で押

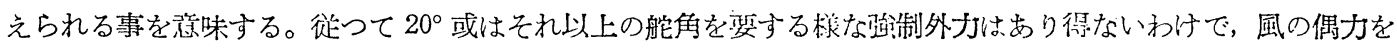
十分押光るに足る舵角を限度として拥兄る事山必管である。

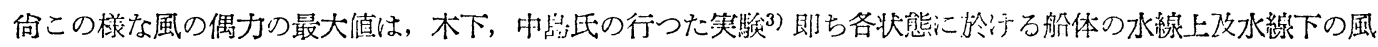
王中心及び抵抗係数を種々の迎侍につき求める事により推定出来る。

\section{附録 1. 蛇航遠心力による抵抗増加}

蛇航の最大俑速度を $w$ とすれば

邀心力の船体中心線方向つ分力は5)より

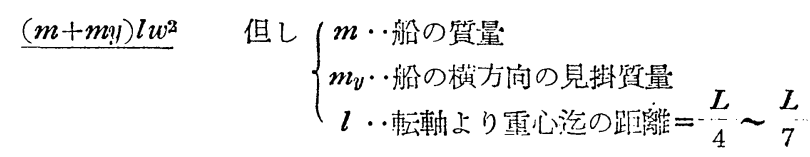

之が週知的に憉くから平均として

$$
\begin{aligned}
& R=\frac{2}{\pi}\left(m+m_{y}\right) l w_{2} \\
& l=21.3 m \\
& m_{y} \fallingdotseq m \\
& m+m_{y}=\frac{2 W}{g} \quad W=13,500 \mathrm{t} \\
& w=\frac{2 \pi}{\tau} \theta y
\end{aligned}
$$

\begin{tabular}{|c|c|c|c|c|}
\hline No. & $\theta_{y}$ & $\tau$ & $w$ & $R$ \\
\hline 62 & $6^{\circ}$ & $70 \mathrm{sec}$ & .00938 & $3.23 \mathrm{t}-\mathrm{m}$ \\
\hline 63 & $5^{\circ}$ & "I & .00783 & 2.25 \\
\hline 74 & $5^{\circ}$ & $" \prime$ & $" \prime$ & $2.2 \overline{5}$ \\
\hline
\end{tabular}

๖して計算すると

\section{附録 2. 舵 の 抵 抗}

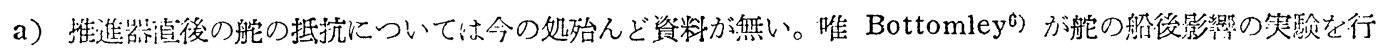
つているのでその data を参照すると，

舵值 $15^{\circ}$ で

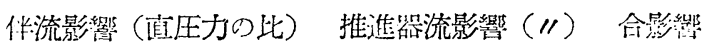

$$
\begin{aligned}
& \begin{array}{lll}
0.40 & 2.40 & 0.97
\end{array}
\end{aligned}
$$

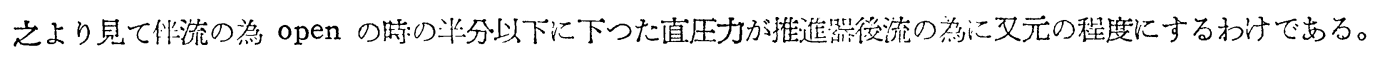
之上り見て舵の大部分山摧進器後流中心あつて，その流速を受けると浖えられる。

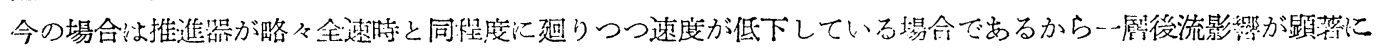
現われるわけである。 
今舵の面積の $90 \%$ は推進器後流の中に没しそれ以外は流中にあるとすると

船 速 $\quad V$
伴流率 $w$

推進出後流 $\quad V_{p}=V_{p_{0}} \times \frac{n}{n_{0}}$

舵の或角度に於计る抵抗係数を $C_{D}$ とすると

$$
\text { 舵の抵抗 } R_{r}=\frac{1}{2} \rho A C_{D}\left\{0.9 \times V_{p_{0}}^{2} \times\left(-\frac{n}{n_{0}}\right)^{2}+0.1 V-(1-w)^{2}\right\}
$$

で大体算出し得る。

b) 次に抵抗係数は舵角が変動するのでその平均を取るわけであるが，舵角と $C_{D}$ は比例しないので第 8 図の

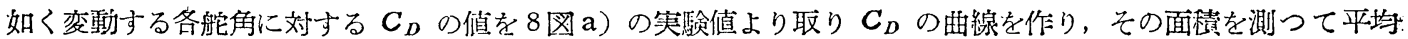
を取る。かくして得られた $C_{D}$ の值を用いて代表的な数例について計算して見ると，

$$
w=0.25 \quad n_{0}=99 \quad V_{p_{0}}=6.83 \mathrm{~m} / \mathrm{sec} . \quad A=15.9 \mathrm{~m}^{3}
$$

等の数值より下表つ如くなる。

\begin{tabular}{c|c|c|c|c|c}
\hline No. & $\boldsymbol{V}$ & $\boldsymbol{V}_{\boldsymbol{p}}$ & $\boldsymbol{n}$ & $\overline{\boldsymbol{C}_{\boldsymbol{D}}}$ & $\boldsymbol{R}_{\boldsymbol{r}}$ \\
\hline 62 & 5.12 & 6.18 & 89.4 & 0.074 & $2.25 \mathrm{t}$ \\
63 & 4.46 & 6.03 & 87.2 & 0.0922 & $2.59 \mathrm{t}$ \\
74 & 4.48 & 6.02 & 87.1 & 0.0494 & $1.33 \mathrm{t}$ \\
\hline
\end{tabular}
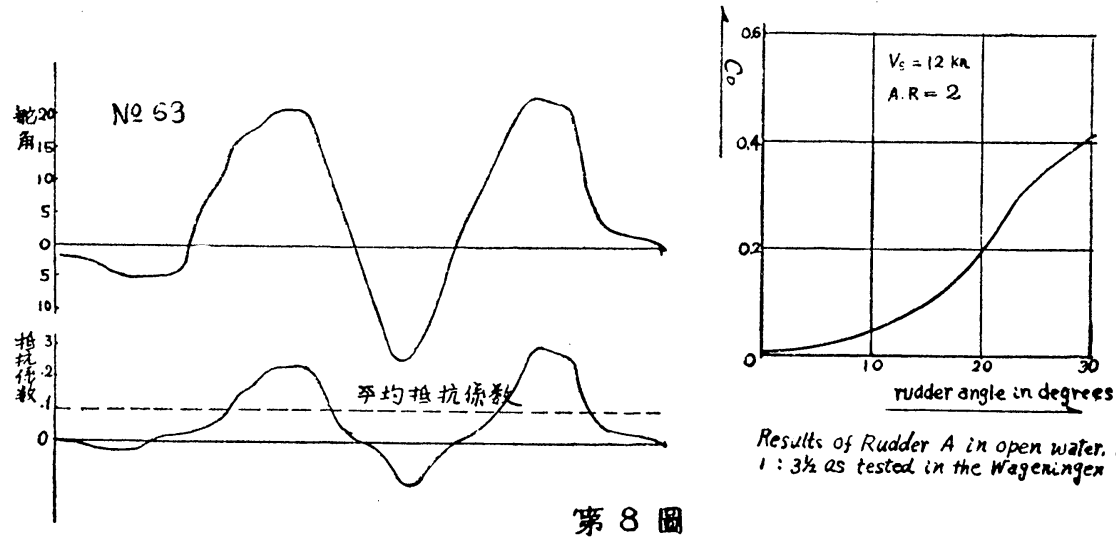

Results of Rudder $A$ in open water. model scate. $1: 3 y_{2}$ as tested in the Wageningex Tant

第 8 圆

参 考 文 献

1）元良誠三：強制外力による船首摇れについて，造船協会々報 83 号.

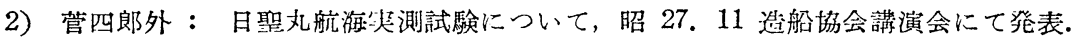

3）中島康吉：鉄道連絡船の操縱性に及ぼす風の影響，造船協会論交集 84 号.

4) Directional Stability of Automatically Steered Body. Minorsky, N., TSNA_1922.

5）元良誠三：航路安定性について，昭 21. 11 造船協会满演会にて発表

6) Manoeuvering of. Ships part I, part II Baker G.S., \& Bottomley.G.H. I.E. \& S. Scotld. $1921 \sim 1922$. 